\title{
UNIQUE PRESERVATION OF SILICEOUS DINOFLAGELLATE MOTILE CELLS FROM THE OLIGOCENE FOSSIL-LAGERSTÄTTE OF SIEBLOS, GERMANY
}

IAN C. HARDING ${ }^{1}$

${ }^{1}$ School of Ocean \& Earth Science, University of Southampton, National Oceanography Centre Southampton, European Way, Southampton, SO14 3ZH, England.

E-mail: ich@noc.soton.ac.uk

\section{ABSTRACT}

The Triassic to Recent fossil record of the dinoflagellates is represented overwhelmingly by geologically resistant, organic-walled, non-motile resting cysts; such cysts are formed following the sexual phase in the life cycle. Very few confirmed records exist of the motile stage being preserved in the fossil record. This paper reports the occurrence of two very unusual dinoflagellate taphofacies, one developed in bituminous shales and the other in micrites, from the Oligocene fossil lagerstätte at Sieblos, Hesse, Germany. A new dinoflagellate taxon, Sieblososphaera martini n. sp. has been identified through analysis of dissociated skeletal elements in the bituminous shales and external moulds and casts in the micrites. The unique preservation of these fossils confirms them not only as primary biogenically silicified motile thecate cells, but also indicates that there was a much greater range of tabulation present within the subfamily Lithoperidiniaceae than has hitherto been recognised.

Key words: Oligocene, dinoflagellate, theca, taphonomy, lagerstätte, Sieblos 
OUR UNDERSTANDING of the fossil record of multicellular macroscopic organisms has been revolutionised by the study of exceptionally well-preserved fossil assemblages. By comparison, proportionally many fewer exceptionally preserved microscopic organisms have been described. These latter investigations have revealed exceptionally well-preserved microfossil biotas of groups such as the crustacea (e.g. Siveter et al. 2003, 2010; Matzke-Karasz et al. 2009; Lepure et al., 2012), calcareous nannoplankton (e.g. Bown et al. 2008; Dunkley Jones et al. 2009), and diatoms (Wolfe et al. 2006). Conversely numerous taphonomic investigations have focused on determining the relationships between bio- and thanatocoenoses of extant micropalaeontological groups (e.g. Martin et al. 1999). Even by comparison with other microfossil groups, dinoflagellates have received relatively little attention with respect to taphonomy or exceptional preservation. However, there have been several papers that have explored the resistance of dinoflagellate cysts to oxidation processes, either in nature (Zonneveld et al. 1997, 2001, 2007, 2008, 2010; Zonneveld and Brummer 2000; Versteegh and Zonneveld 2002; Bockelmann et al. 2007; Kodrans-Nsiah et al. 2009; Gray et al. 2017; Zonneveld et al. 2019), or in sample processing (e.g. Schrank 1988; Hopkins \& McCarthy 2010). All of these studies involved organic-walled dinoflagellate fossils, which represent the most commonly studied fraction of the dinoflagellate fossil record. Exceptionally well-preserved calcareous dinoflagellate cyst assemblages have been reported (e.g. Streng et al. 2009), but no taphonomic investigations of siliceous dinoflagellates have yet been published.

In this context, this paper describes a study of the taphonomy of siliceous dinoflagellate fossils found in an Oligocene fossil conservation lagerstätte from Sieblos, in the Hesse region of Germany (Martini \& Rothe 1993). The unusual preservational styles of these siliceous fossils permits the assessment of two contentious questions pertaining to the non-spiculate siliceous dinoflagellate fossil record: whether the remains represent the motile (swimming) cells or are the resting cysts formed after sexual reproduction; and whether the silicification of these fossils is primary biosynthesis or secondary diagenetic replacement. 
Many dinoflagellates have two phases in their life-cycles (e.g. Fensome et al. 1993). The first of these to be recognised was the swimming or motile stage, in which the cell is enclosed by an outer cortex (the amphiesma); this contains vesicles or "alveolae", a characteristic that places the dinoflagellates within the Alveolata (Cavalier-Smith 1991; Fensome et al. 1993, 1999). The amphiesma of those motile dinoflagellates referred to as 'naked', 'unarmoured' or 'athecate' may derive rigidity from the large numbers of small, 'empty' vesicles in the amphiesma. However, in many forms the amphiesmal vesicles are large and fewer in number, and are the sites where cellulosic ('thecal') plates are secreted. These are the thecate or 'armoured' dinoflagellates. The shape and arrangement of the cellulosic plates of thecate dinoflagellates define a tabulation, the pattern or arrangement of which is of taxonomic importance. The thecal plates usually overlap, with growth of both the vegetative theca and the sexually produced theca accomplished by the deposition of additional cellulose around the margins of each plate ('growth bands'). As the thecal plates are secreted within separate vesicles, they are independent 'units' and contact adjacent plates along functional sutures. During vegetative reproduction and upon the death of the organism the individual cellulosic plates may separate or disaggregate along these functional plate boundaries.

In the nineteenth century, workers such as Ehrenberg (1854) believed that dinoflagellate fossils discovered in Cretaceous flint nodules were preserved thecate stages, but fossilised motile stages are now known to be extremely rare in the fossil record (see Evitt 1985, p. 36), due to the geologically volatile nature of the cellulose of which they are/were constructed (Allison and Briggs 1991). Thus, the fossil record of dinoflagellates understood to be dominated by resistant cysts produced following the sexual phase of the life cycle (Evitt 1985). The resting cysts produced by many dinoflagellates (a diploid hypnozygote, often referred to as a 'dinocyst') may possess an organic or mineralised wall. Those with organic walls may be composed either of cellulose (as in the freshwater ceratioids), or constructed of a refractory compound often referred to as 'dinosporin' (Fensome et al. 1993). The chemistry of this complex biopolymer is slowly becoming better known, and is now considered to consist of a carbohydrate-based backbone, to which nitrogencontaining moieties have been added in the cyst walls produced by heterotrophic dinoflagellates 
(Hemsley et al. 1994; Kokinos et al. 1998; de Leeuw et al. 2006; Bogus et al. 2012; Versteegh et al. 2012; Gurdebeke et al. 2018). In contrast to motile thecate forms, the only functional sutures in the dinocyst wall are those associated with the pre-determined excystment opening or archeopyle (e.g. Fensome et al. 1993), and indeed many dinocysts lack any surficial expression of the tabulation of the parent theca.

It is now accepted that the vast majority of the dinoflagellate fossil record is represented by resting cysts, examples of preserved motile stages being extremely rare. These few examples comprise the exceptionally preserved dinoflagellate thecal remains discovered in Cretaceous amber (Masure et al. 2013), the dinosporin-impregnated 'pellicles' of the late Cretaceous subfamily Dinogymnioideae (Sarjeant \& Downie) Fensome et al. 1993 (see May 1976, 1977), and the calcareous wall covering of the coccoid vegetative cells of the order Thoracosphaerales Tangen (in Tangen et al. 1982). The strange spongy 'casts' of gonyaulacoid dinoflagellates from the Eocene of Pakistan may also be preserved thecal stages (Versteegh et al. 2004). Finally, and although somewhat different in nature, the inside surface of the extra-thecal wall of Palaeoperidinium pyrophorum was elegantly shown to reflect the morphology of the parent dinoflagellate theca around which the wall formed by Evitt et al. (1998).

\section{Siliceous dinoflagellates: an enigmatic group}

In addition to cellulose, 'dinosporin' and calcite, some dinoflagellates are able to synthesise silica. Silica biosynthesis is best known in the gymnodinialean family Actinisaceae Fensome et al., 1993, in which a pair of internal skeletal elements or spicules with four to six radiating arms are secreted around the cell nucleus. This group has a known fossil record ranging from the Oligocene to the present day (Ernisse \& McCartney 1993). Chapman et al. (1982) identified silica as a minor component of the cellulosic resting cyst of the extant ceratioid Ceratium hirundinella (O.F. Müller) Dujardin, 1841, and silica is also the presumed composition of the acid-resistant $Y$-shaped internal spicule of the family Dicroeriismaceae Fensome et al., 1993, a group closely related to the actiniscaceans, but with no known fossil record. 
The only other known siliceous dinoflagellate body fossils are allocated to two genera in the subfamily Lithoperidinioideae (Deflandre) Fensome et al., 1993, of the peridinialean suborder Peridiniineae. These two genera, now considered synonymous, were both defined in the same year: Lithoperidinium by Deflandre (1933), and Peridinites by Lefèvre (1933a). The former is now taken as the senior synonym (see discussion in Fensome et al. 1993). To these forms may be added the genus Jusella Vozzhennikova, 1963, the wall composition of which is acid-resistant, although not definitively known to be siliceous (Lentin, quoted in Fensome et al. 1993: p. 137). There remain many unanswered questions about the nature of the lithoperidinioideans: do they represent siliceous cysts or siliceous thecae; and is the silicification primary (i.e. the product of biosynthesis) or secondary (i.e. diagenetic; Harding and Lewis 1994)?

Sampling of material from Lefèvre's rediscovered type locality in the Scotland District of Barbados resulted in the isolation of new specimens (Harding and Lewis 1994; Harding 1996), with which it was hoped this enigma could be solved. Study of the new specimens revealed two types of siliceous body fossils, representing both fossilised cysts and motile thecae. The former specimens demonstrate non-functional (para-)sutures which delineate a reduced paratabulation, in conjunction with non-functional cingular and sulcal grooves. However, the majority of the Barbadian specimens were shown to be composed of individual siliceous plates, separated by functional sutures. These specimens also possessed unobstructed cingular and sulcal areas which could have housed functional flagella. In addition, the large pore(s) completely penetrating plates in the sulcal region of these specimens appeared compatible with the openings for flagella. The siliceous plates were also perforated by pores, which were identified as having been associated with trichocysts in the living motile stage. Combined together, these features indicated that this numerically dominant group of specimens could only be interpreted as fossil dinoflagellate thecae that, during vegetative binary fission, emerged through an unusual hypothecal ecdysal opening in the post-cingular plate series.

Furthermore, the Barbadian samples showed evidence of active silica dissolution rather than secondary silicification, as many other siliceous components of the recovered assemblage (the 
fragile centric diatoms in particular) were corroded. This was the first strong evidence to indicate that the specimens represented both bio-silicified thecal plates secreted by the motile dinoflagellate cell and primarily silicified cysts. No corroborative evidence to substantiate these claims has yet emerged. However, examination of fossil microplankton from the German fossilpreservational lagerstätte at Sieblos has identified another instance of motile stage preservation; it has confirmed that silica mineralisation was primary and biogenic, and also shown that another taxonomic group of dinoflagellates was capable of silica biomineralisation.

\section{GEOLOGICAL SETTING}

During the nineteenth and earliest twentieth centuries a pit close to the town of Sieblos in Hesse, Germany (Fig. 1), was mined for its kaolinite and bituminous shales. The shales have been described (incorrectly) as 'Braunkohle' by some earlier authors (e.g. Gahl 1968), and also as 'dysodil' by others (e.g. Martini \& Rothe 1993). Several shafts and many galleries were dug into the shales, and the bituminous material was sent via a suspension railway to a distillation plant nearby for the extraction of hydrocarbons. The Sieblos deposits, of presumed Oligocene (Rupelian/Latdorfian) age (Martini \& Schrader 1988; Martini \& Rothe 1998; Mai 2007), became well known to German palaeontologists in the latter half of the nineteenth century (e.g. Hassenkamp 1858), and have subsequently yielded perfectly articulated vertebrates. These have included fossil fish (Martini 1965a, b. 1988a), frogs, tadpoles, crocodiles and snakes (Gaudant 1985; Schleich 1988), rare birds (Martini 1988b) and bats, one of which has preserved stomach contents (Richter \& Storch 1988). The deposit also contains abundant gastropods (Kadolsky 1988), insects (Willmann 1988; Lutz 1998), and a diverse flora of leaves (Jähnichen \& Rüffle 1988) and seeds (Mai 1998), although the spore and pollen floras are impoverished (Gahl 1964; Hottenrott 1988). Microfossil remains include ostracods (Malz 1988; Schiller 1998), the freshwater alga Botryococcus (Martini 1993), charophytes (Schwarz 1988, 1998), diatoms, chrysophycean cysts, and a single species of calcareous nannoplankton (Martini 1987; Martini \& Schrader 1988; Martini \& Schiller 1998; Schiller 1998). Siliceous dinoflagellate fossils were first reported by Martini \& Schrader (1988), and were subsequently mentioned by Martini \& Rothe (1998), Martini \& Weiler (1998) and Schiller (1998). 
The nature of the sedimentary succession at Sieblos was (poorly) known from nineteenth century reports (compiled by Gahl 1968), but appeared to display substantial lateral lithological variation and differences in bed thicknesses. As the Sieblos pit is now overgrown, most of the specimens had been collected from old mining dumps. To define the stratigraphic sequence at Sieblos better, and to provide a context for the different lithologies collected from the old mine workings, four new boreholes were drilled through the succession in the 1990s. Two of these cores were drilled in 1994 (Martini \& Rothe 1998), and one each in 1998 and 1999 (Martini, pers. comm.; Fig. 2). Local 'basement' consists of Triassic sediments, overlain by Eocene-Oligocene sands and mudstones (e.g. Rothe 2006).

The Sieblos Shales lie above these sediments and are themselves dominated by sands and mudstones, with subordinate laminated bituminous shales, calcareous mudstones and micrites. The micrites and laminated bituminous shales contain diatoms, chrysophyte cysts, calcareous nannoplankton, testate amoebae, sponge spicules and dinoflagellate fossils. The unusual combination of microfossils of both marine and non-marine affinity has made the interpretation of the palaeoenvironmental conditions under which the deposit developed problematic.

The Sieblos Shales had been interpreted as recording sporadic marine influxes into the area during sea-level highstands (Rupelian/Latdorfian: NP 21/22, 35 Ma; Martini \& Schrader 1988; Martini \& Rothe 1998). Although local Oligocene palaeogeography is still not well known, the Sieblos depocentre may have been periodically connected to a southerly extension of the North Sea Basin, which reached down into the northern Rhine Graben (Martini 1990, 1991; Fig. 1). However, the current consensus, partly based on geochemical data (Rothe 2006), is that the shales were deposited in a lacustrine setting, with those fossils of a more 'marine' affinity having populated the lake body during more arid climatic phases where evaporation exceeded precipitation and strongly salinity stratified conditions were established within the water column (e.g. Schiller 1998). Similar palaeoenvironmental scenarios have been suggested for other sites at 
Nördlinger Ries and Beuern/Vogelsberg (e.g. Schauderna 1983 and Krasske 1934, respectively; Martini \& Rothe 1998). The Oligocene succession is overlain by Neogene tuffs (Martini 1993).

\section{MATERIAL AND METHODS}

All specimens were examined in the scanning electron microscope (SEM) by surveying the surfaces of both mechanically fractured surfaces of rock chips and polished thin sections, both from samples provided by Prof. Dr. Erlend Martini (Geologish-Paläontologishes Institut, Johann Wolfgang Goethe-Universität, Frankfurt am Main). The material was collected either as weathered samples from the mine dump or provided as fresh samples from the core material drilled in 1994.

Secondary electron microscope imaging was conducted on fractured surfaces of sediment chips glued onto aluminium SEM pin stubs. The specimens were coated with gold in a Hummer VI-A sputter-coater. Typical thicknesses for both gold and carbon coatings was about $20 \mathrm{~nm}$, to create electrically conductive surfaces. Electron microscopy was conducted using a Leo 1450VP (variable pressure) scanning electron microscope. Secondary electron images (SEIs) were obtained using operating conditions of $15 \mathrm{kV}$, a nominal probe current of $120 \mathrm{pA}$ and a working distance of $14 \mathrm{~mm}$. Digital inversion of the SEls of external moulds of the dinoflagellate fossils using CorelDRAW ${ }^{\circledR}$ to produce a 'positive' image of the specimen. This simple digital manipulation facilitated the visualisation of the original external surface of the specimen.

Analysis of the sediment fabric was conducted using backscattered electron imaging (BSEI) on polished thin sections of sediment ( $200-300 \mu \mathrm{m}$ thick) cemented onto $3 \times 5 \mathrm{~cm}$ glass slides. The polished thin sections were coated with $\sim 20 \mathrm{~nm}$ of carbon in an Edwards Auto 306 carbon coater to enable X-ray microanalysis. These analyses used an EHT of $15 \mathrm{kV}$ with a nominal probe current of $1.4 \mathrm{nA}$, and a working distance of $19 \mathrm{~mm}$. Elemental analyses were conducted using a PGT energy dispersive X-ray microanalysis system and light element detector, and spectra processed using the Phi-Rho-Z technique. 
All figured specimens are deposited at the Sedgwick Museum, University of Cambridge, Cambridge, England (CAMSM).

\section{RESULTS}

The distinctly and finely laminated pelagic/hemipelagic sediments found at Sieblos record sequential biogenic and lithogenic flux events. These were preserved as discrete laminae due to a lack of both bottom water current activity and bioturbation, likely the result of water column stratification resulting in low oxygen levels in the profundal waters of the basin (see Baumgartner et al. 1989; Kemp et al. 2000, 2001). Backscattered electron microscope imaging analysis of polished thin sections of the sediments indicates a regular repetition of compositionally distinct laminae, which probably preserve a record of seasonal plankton succession and sedimentation. Although these vertically repeated successions of compositionally distinct laminae have not been incontrovertibly determined to record an annual sediment flux, for the sake of convenience they will be referred to here as comprising 'varves'. The siliceous dinoflagellate fossils found in these sediments have two distinct styles of preservation resulting from two distinct depositional and postmortem mechanisms. These two distinct modes of occurrence are described below as Taphofacies 1 and Taphofacies 2, each description being followed by a discussion of the depositional history of each facies.

\section{Taphofacies 1}

Taphofacies 1 is developed in the bituminous shales, and the siliceous dinoflagellate fossils were found in lamina-scale concentrations as separated and dissociated individual skeletal elements (Fig. 3). The varves in the bituminous shales vary both in thickness and in the number of compositionally distinct laminae they contain. Thinner varves consist of two successively repeated laminae and are some 30-40 $\mu \mathrm{m}$ thick, whilst more complex varves consist of three successive and repeating laminae of different compositions, up to $600 \mu \mathrm{m}$ thick.

The thinner varved couplets average around $30 \mu \mathrm{m}$ in thickness, the majority consisting of a lower lamina composed of aggregations of dinoflagellate skeletal elements (Fig. 3). These laminae 
contain rare silt grains, but the highest concentrations of silt and clay are found in very poorly developed, discontinuous 'laminae' up to $10 \mu \mathrm{m}$ thick which overly the lower lamina (best seen in couplets 1 and 7, Fig. 3C, and couplet 5 in Fig. 3D). Chrysophyte cysts may be found randomly distributed within the dinoflagellate laminae (Fig. 3C, E) and very rarely in sufficient concentrations to form thin laminae $(\sim 2-5 \mu \mathrm{m}$ thick) underlying the dinoflagellate-dominated laminae.

The thicker varves within the bituminous shales consist of three compositionally distinct laminae, up to $600 \mu \mathrm{m}$ thick, less commonly developed than the thinner couplets described above, and demonstrating more lateral variability in laminar thickness. The lower lamina is co-dominated by elongate pennate diatoms (Fig. 3F \& I) and dissociated dinoflagellate skeletal elements, with occasional sponge spicules and flocs of chrysophyte cysts (up to a maximum of $400 \mu \mathrm{m}$ thick; lamina 1 in Fig. 3J). The second lamina in these thicker successions is co-dominated by disaggregated dinoflagellate skeletal elements and resting spores of a diatom resembling Chaetoceras. These laminae demonstrate a gradual increase in clay/organic content, grading into the third and topmost hemipelagic lamina, often incompletely developed which contain sporadic silt grains. Organic material is dispersed through all three laminae. Some of the skeletal elements (diatoms, dinoflagellates and sponge spicules) in these bituminous shale laminae have been pyritised (and appear white in the BSEls, see Fig. 3D, E, J).

Discussion. Secondary electron imaging of laminar surfaces shows that the dinoflagellate skeletal remains are represented as individual polygonal plates that preserve their internal and external morphologies with high fidelity (Fig. 3A, B, F-H). The plates display entire margins, are largely free from mechanical breakages, and are completely penetrated by pores (Fig. 3A, B, F, G). All of the plates in the peridinioid tabulation are recognisable (Fig. 3A). These features indicate that these elements represent the thecal plates of a motile/swimming dinoflagellate cell that have disaggregated naturally along functional plate sutures. Whilst the plates usually appear to have a random distribution across the surface of an individual lamination, by determining the Kofoidian plate designation, certain adjacent plates can be identified as representing a single disaggregated dinoflagellate motile cell. EDX analysis of specimens has indicated that the plates have a siliceous 
composition. No evidence for etching, corrosion or diagenetic overgrowth occurs on any of the siliceous elements in the assemblage, indicating that the vast majority of the silica was formed by primary biomineralisation processes.

The biogenic laminae are taken to represent probable spring/summer plankton blooms with the overlying clay/silt/organic laminae having been deposited in the autumn/winter. The biogenic laminae reflect the self-sedimentation of successive planktonic blooms, the thicker three-layered varves representing seasonal bloom successions that began with early pennate diatoms mixed with siliceous dinoflagellates. Later, as the dinoflagellate population bloomed it diluted the pennate diatoms. Diatom resting cysts (similar to those produced by Chaetoceras) are found incorporated with the dinoflagellate remains towards the end of the dinoflagellate-dominated laminae. As planktonic productivity decreased later in the season, hemipelagic sedimentation of clay and silt completed the presumed annual laminar sequence. The low-oxygen bottom water conditions excluded benthos, promoting the preservation of the laminated sediments.

Whether the dinoflagellate thecal remains descended to the basin floor as individual cells, flocs or some other form of aggregates, or inside faecal pellets, the thecal plates appear to have become dissociated. This may have been the result of the cells having been digested, or simply as a result of bacterial breakdown of the organic cell wall which liberated the individual siliceous thecal plates.

The dominantly siliceous content of the planktonic laminae is evidence for high surface-water productivity enhancing the deposition and preservation of biogenic silica. No evidence exists for diagenetic dissolution due to silica phase changes, specifically the time/temperature/burial depth dependent phase change from opal-A to opal-CT which is known to convert many diatom assemblages to moulds (Kakuwa 1984). The detrital clays may have helped to retard this process by promoting Al-armouring of the siliceous skeletons (Thein and von Rad 1987; Van Beusekom et al. 1997). The nature of the pyritisation is of note, in that there has been pyrite replacement of some siliceous dinoflagellate thecal plates, diatom frustules and sponge spicules. It is more usual to find pyrite growing in the chemical microenvironments inside frustules, etc., and producing 
steinkerns rather than replacing the silica. The fidelity of the replacement has preserved both the central canals in sponge spicules and trichocyst pores in the dinoflagellate thecal plates.

Replacement must therefore have occurred while the silica was still in the form of opal-A, and was gradual, the fine structure of the silica matrix restricting the ultimate size of pyrite microcrystals (e.g. Kaczmarska and Erhman 1990).

\section{Taphofacies 2}

The second taphofacies is developed in the micritic horizons, and here the dinoflagellates are represented both as external moulds and somewhat less usually as internal casts of entire, articulated individuals which retain their original three-dimensional morphology (Fig. 4A-C, F, H, I). External moulds of disaggregated skeletal elements are also found. The laminar successions in the micrites is more consistent than in the bituminous mudstones, although individual laminae vary in thickness from around 100 to $300 \mu \mathrm{m}$ (Fig. 4D, E, G, J). Each varve consists of four individual laminae. The first lamina is composed of small pennate diatoms and is $30-150 \mu m$ thick. This is then overlain by a second lamina in which pennate diatoms and dinoflagellate skeletal remains cooccur, often dominated by the latter component and $\sim 50-200 \mu \mathrm{m}$ thick (Fig. 4D, E, G). An often discontinuous third lamina is found above this, comprising articulated, three-dimensionally preserved, smooth-walled ostracods identified as Metacypris (Fig. 4D, E). The fourth lamina is clay rich and rarely exceeds $20 \mu \mathrm{m}$ in thickness. As in the case of Taphofacies 1 , monospecific laminae of chrysophyte cysts appear sporadically (e.g. Fig. 4B, C), but in this component appears to have no consistent stratigraphic relationship to the other laminae.

Discussion. The bloom sequence evidenced in Taphofacies 2 commenced with a population of small pennate diatoms, the diatoms bloom was later diluted as the dinoflagellates bloomed and took over as the donimany component of the plankton. Successive remains of these bloom populations sank to the basin floor along with micritic calcite that was precipitating in the overlying water column. This sediment flux was sporadically supplemented with lower concentration 'dumps' of chrysophyte blooms. The repeated influxes of ostracods may represent mass mortality events (possibly related to overturn of the lake waters), with the articulated carapaces of dead individuals 
collecting above the dinoflagellate-dominated laminae. The thin clay/silt laminae were again introduced as the last phase of sedimentation in each cycle.

The extremely fine-grained nature of the micritic sediment preserves perfect external moulds of the dinoflagellate specimens. The internal casts found inside many of the three-dimensional dinoflagellate specimens (Fig. 4A-C, H) have also been identified as calcareous by EDX analysis, and demonstrate later secondary precipitation of calcium carbonate. The calcareous matrix shows evidence for overgrowths and pore-filling cements throughout the micritic laminae. The siliceous skeletons of the dinoflagellates were (almost entirely) dissolved away after secondary calcite precipitation, rendering the majority of the dinoflagellate remains preserved as mouldic porosity (cf. Martini \& Weiler 1998; Fig. 4B, C, F-J).

By comparing the morphology of the thecal plates preserved in Taphofacies 1 with the digitally inverted images of the external moulds templating the thecal plates in Taphofacies 2, it can be demonstrated that the remains all present a single species of dinoflagellate, and this new taxon is described below.

\section{SYSTEMATIC PALAEONTOLOGY}

Division DINOFLAGELLATA (Bütschli 1885) Fensome et al., 1993

Subdivision DINOKARYOTA Fensome et al., 1993

Class DINOPHYCEAE Pascher, 1914

Subclass PERIDINIPHYCIDAE Fensome et al., 1993

Order PERIDINIALES Haeckel, 1894

Suborder PERIDINIINEAE

Family PERIDINIACEAE Ehrenberg, 1831

Subfamily LITHOPERIDINIACEAE (Deflandre 1945) Fensome et al., 1993 


\section{Genus SIEBLOSOSPHAERA nov.}

Derivation of name. After Sieblos, the location from which the specimens originate, in Hesse, Germany, and sphaera - the Greek for spherical.

Type. Sieblososphaera martinii n. sp. by monotypy.

Diagnosis. As for the type and only known species.

Sieblososphaera martinii n. sp.

Figures 5, 6

Derivation of specific name. After Prof. Dr. Erlend Martini, formerly of Johann Wolfgang GeotheUniversität, Frankfurt am Main, who studied the Sieblos locality for many years and first alerted the author to these siliceous dinoflagellate fossils.

Holotype. Figure 5J, Sieblos borehole 1994/2, 29.4 m. Specimen 15 on SEM Stub 1994/2, $29.40 \mathrm{~m}$, accession number SEDG X 50335 ba.

Repository. The holotype and other illustrated specimens are deposited in the Sedgwick Museum, University of Cambridge, Cambridge, England.

Type material. Laminated micrites identified as the Sieblos Shales in the 1994/2 core at $29.40 \mathrm{~m}$, Sieblos, Hesse, Germany; age believed to be Rupelian ('Latdorfian'), Oligocene.

Diagnosis. A species of primarily siliceous dinoflagellate theca with peridiniacean tabulation, including only two anterior intercalary plates. 


\section{Description.}

Shape. Ambitus is of circular to slightly prolate ovoidal aspect. The hyposome and episome are of approximately equal dimensions (Fig. 5B, J); the episome may show a slight apical prominence around the apical pore area (Fig. 5J, 6B, 6F). In equatorial view the specimens are essentially circular (Fig. 5D, E).

Cingulum. Between 2.5 and $4 \mu \mathrm{m}$ in width (left adsulcal section of cingulum slightly wider than right in a single specimen), moderately depressed; descending, displaced by a half to one cingulum width (Figs 5B, F, H, J; 6F, I). The cingulum is bordered by ridges or septa developed on the precingular plate series, but whereas the cingular plates are strongly reticulate like the other plates, they do not have sutural ridges and thus provide an unobstructed cingular groove (Fig. 5B, C, F, I). The six cingular plates are generally smooth on the interior surface and perforated by trichocyst pores, which emerge as collared holes in the base of external reticular lumina (Fig. 6L, lowest arrow).

Sulcus. Consisting of four plates: as, Is, rs and ps (Figs $5 \mathrm{G}, \mathrm{J} ; 6 \mathrm{G}, \mathrm{H}, \mathrm{J}, \mathrm{K}$ ). The apical margin of the anterior sulcal is usually just higher than the left-hand side of the cingulum and thus extends slightly onto the episome (Fig. $5 \mathrm{~F}, \mathrm{H}-\mathrm{J}$ ). Sulcus is $4-5 \mu \mathrm{m}$ wide between cingular plates, expanding to $6-8 \mu \mathrm{m}$ across the spatulate posterior sulcal. The right sulcal margin is straight but the posterior sulcal bulges to the left $(\mathrm{Fig} .6 \mathrm{H}, \mathrm{J})$. A prominent reticulum is developed on the anterior and right sulcal plates, but less developed on the left and posterior sulcals; the latter can be almost laevigate and has a high ridge on its right-hand side (Fig. $6 \mathrm{H}, \mathrm{J}, \mathrm{K})$. The posterior and right sulcals are each perforated by a single row of prominent trichocyst pores (Fig. $6 \mathrm{H}, \mathrm{J}$. K). The longitudinal flagellar opening is located in a prominent groove immediately to the left of the right sulcal and below the left sulcal (Fig. 6J, K), the transverse flagellar pore is less well marked.

Size. Given the way the specimens are embedded in the sediment matrix it is difficult to find specimens that are sufficiently exposed on the rock chip surfaces to determine complete lengths and widths; thus measurements should be regarded as close approximations. Holotype: $\sim 35 \mu \mathrm{m}$ 
wide/diameter $x \sim 45 \mu \mathrm{m}$ long (partially embedded in matrix). Other specimens 30 (34) $37 \mathrm{~m}$ wide/diameter; 40 (42) $49 \mu \mathrm{m}$ long (14 specimens measured).

Tabulation. The tabulation formula of these thecal fossils is: 4', 2a, 7", 6c, 4s, 5"', 2"'” (Fig. 7), and thus fits within the variation known for the suborder Peridiniineae. In addition there is evidence for an apical pore, and also a small canal plate. The two hexagonal anterior intercalary plates (1a, 2a) are arranged symmetrically about the dorsal midline (Fig. 7). Thus the fourth precingular plate (4") is camerate. The second apical plate is slightly smaller than the fourth. There are six cingular plates, but no transitional cingular. There are four suclal plates, as described above. The five postcingular and two antapical plates are conventionally peridiniacean in their topologies.

Plate overlap (tegulation/imbrication) formula. Using the scheme devised by Below (1987), the tegulation formula can be determined as $2^{*}, 4^{* *}, 4^{* * *}, 3^{* * *}$ (episome); $1 c^{*}, 2 c^{* *}, 2 c^{* * *}, 1 c^{* * * *}$ (cingulum); 3*, 4**, 3*** (hyposome); see Figure 8.

\section{Remarks}

The discovery of laminae preserving dissociated siliceous plates in Taphofacies 1 demonstrates that the dinoflagellate cell walls have totally dissociated along every plate boundary. There are no dinoflagellate resting cysts that are known to completely disintegrate along every paraplate boundary, and thus these fossils must represent the motile thecal stage of the dinoflagellate lifecycle. This is further corroborated by the lack of obstruction along the cingulum and sulcus by parasutural ridges in the three-dimensionally preserved specimens. Both the intra-plate pores which penetrate the entire thickness of the siliceous plates and the large pores in the sulcal region of the three-dimensionally preserved specimens can be identified as representing functional trichocyst pores and flagellar pores respectively. All of these morphological characteristics confirm the thecal nature of these fossils. Whilst no ecdysal opening has been found in any of the threedimensionally preserved specimens studied, this may partly be due to the difficulties of examining 
both dorsal and ventral surfaces of complete specimens, which are preserved as internal casts/external moulds within the rock matrix.

The tabulation of this new taxon is unusual and merits further discussion. The majority of peridiniinean dinoflagellate episomal tabulation schemes include three anterior intercalary plates, and these can be arranged in two different topologies, 'bipesioid' and 'cinctioid' arrangements. Bipesioid tabulation includes a linteloid second anterior intercalary plate (2a) stacked symmetrically above the planate fourth precingular (4") and below the third apical plate (3'; Bujak and Davies, 1983, p. 54). In forms showing cinctioid tabulation, the second anterior intercalary is fastigiate and pentagonal in shape and lies anterior to the boundary between the third and fourth precingular plates (3"/4"; Bujak \& Davies 1983). Siliceous peridiniaceans have been allocated to the peridiniacean Lithoperidiniaceae, and the original diagnosis for this subfamily states that they are "apparently typically cinctioid" (Fensome et al. 1993, p. 137), although the same authors also indicate that these forms "may have cinctioid or bipesioid tabulation" (Fensome et al. 1993, p. 128). By comparison, the tabulation of this newly described siliceous taxon is quite different. The episomal tabulation of Sieblososphaera martinii n. sp. consists of only two hexagonal anterior intercalaries, the second of which lies anterior to the 4"/5" boundary. This arrangement of only two anterior intercalary plates symmetrically disposed on the dorsal surface thus represents an entirely new tabulation form for a siliceous dinoflagellate, which raises a question of where within the suborder Peridiniineae it should be placed.

The possession of only two anterior intercalary plates of Sieblososphaera martinii is a feature shared with many taxa within the Family Protoperidiniaceae, including such forms as the nonphotosynthetic Archaeperidinium Jörgensen 1912 and some Protoperidinium species. The presence of only two intercalary plates is rare in the fossil record, with the cyst genus Umbodinium Bint 1983 being one exception. Unfortunately, the only tabulation details for the latter taxon are restricted to the archeopyle margin, rendering its familial placement uncertain and therefore of no assistance in determining the affinity of S. martinii. 
However, as Fensome et al. (1993) point out that episomal tabulation is variable at a subordinal level, and the only stable morphological characteristics that can be used to subdivide peridiniinean families are features of the cingulum. Sieblososphaera martinii possesses six cingular plates rather than the three found in the Protoperidiniaceae, and therefore this feature alone dictates that it should be allocated to the family Perdiniaceae. Its siliceous composition would therefore argue for inclusion within the peridiniacean subfamily Lithoperidinioideae. However, if this is to be accepted, then the diagnosis of the Lithoperidiniaceae must be expanded firstly to encompass a much greater variation in tabulation than has hitherto been recognised within this subfamily, and secondly to admit motile thecal forms as well as resting cysts.

\section{CONCLUSIONS}

Two different taphofacies developed in laminated bituminous shale and micritic lithologies contain specimens of a siliceous dinoflagellate, Sieblososphaera martinii, shown here to represent a rare instance of the preservation of a motile thecal stage in the dinoflagellate life cycle. This new species has been described on the basis of three-dimensional internal casts and external moulds, and this unique style of preservation allows not only a complete reconstruction of the bipesioid tabulation scheme, but also permits the determination of plate overlap patterns and the distribution of trichocyst pores on the theca. Detailed examination of the siliceous fossils in Taphofacies 1 has found no secondary silicification, and in fact slight etching of some of the siliceous microfossils in the assemblage has been observed. This finding corroborates the contention that some dinoflagellate taxa were capable of primary biogenic silica mineralisation. Here it has been shown that silica was synthesised by the motile cell of $S$. martinii in the form of thecal plates. Despite the bipesioid episomal tabulation, it is the cingular tabulation of $S$. martinii that indicates that it be allocated to the family Peridiniaceae, rather than the Protoperidiniaceae. If this new species is then to be accommodated within the Lithoperidinioideae, both cinctioid and bipesioid tabulation styles must be accepted within that subfamily. The geological record of the dinoflagellate motile cell is represented by only a handful of fossils, but the novel preservational mechanism described here indicates the potential for future taphonomic studies to elucidate our understanding of this aspect of the dinoflagellate life cycle. 


\section{ACKNOWLEDGMENTS.}

The author would like to thank the following individuals: Prof. Dr. Erlend Martini for his generosity in providing the sample material and additional information, and to apologise for having taken so long to produce this paper; Dr. Robert Fensome and one other anonymous referee who together provided much constructive commentary for the improvement of the manuscript; Dr. Richard Pearce for his support with scanning electron microscopy.

\section{REFERENCES}

BAUMGARTNER, T.R., MICHAELSEN, J., THOMPSON, L.G., SHEN, G.T., SOUTA, A. and CASEY, R.E. 1989. The recording of interannual climatic change by high-resolution natural systems: tree-rings, coral bands, glacial ice layers, and marine varves. In PATERSON, D.H. (ed.), Aspects of Climate Variability in the Pacific and the Western Americas, Geophysical Monograph Series, 55. American Geophysical Union. doi.org/10.1029/GM055p0001

BINT, A.N. 1983. Umbodinium crustov gen. et sp. nov., a peridinioid dinoflagellate with two intercalaries from the Albian of Kansas. Palynology, 7, 171-182.

BOWN, P.R., DUNKLEY-JONES, T., LEES, J.A., RANDELL, R.D., MIZZI, J.A., PEARSON, P.N., COXALL, H.K., YOUNG, J.R., NICHOLAS, C.J., KAREGA, A., SINGANO, J. and WADE, B.S. 2008. A Paleogene calcareous microfossil Konservat-Lagerstätte from the Kilwa Group of coastal Tanzania. Geological Society of America Bulletin, 120, 3-12.

BUJAK, J.P. and Davies, E.H., 1983. Modern and fossil Peridiniineae. American Association of Stratigraphic Palynologists Contributions Series, 13, 201p.

Bütschli, J.O., 1885. Erster Band. Protozoa. In Bronn, H.G. (Ed.), Klassen and Ordnungen des Their-Reichs, wissenschaftlich dargestellt in Wort und Bild. C.F. Winter-sche Verslagbuchhandlung, Leipzig and Heidelberg, 865-1088. 
Deflandre, G., 1945. Ficher micropaléontologique - série 5. Dinoflagellés II. Gymnodiniales et dinoflagellés incertae sedis. Flagellés incertae sedis. Archives originales, Centre de documentation; Centre national de la recherché scientifique, France, 207, I-XII, fiches 752-859.

DUJARDIN, F. (1841). Histoire naturelle des Zoophytes, Infusoires, comprenant la physiologie et la clasification de ces animaux et la manière de les étudier à l'aide du microscope. Librarie Encyclopédique de Roret, Paris, pp. i-ix, 1-684.

DUNKLEY JONES, T., BOWN, P.R. and PEARSON, P.N. 2009. Exceptionally well preserved upper Eocene to lower Oligocene calcareous nannofossils from the Pande Formation (Kilwa Group), Tanzania. Journal of Systematic Palaeontology, 7, 359-411.

EHRENBERG, C.G. 1831. Animalia evertebrata. In Hemprich, P.C., and Ehrenberg, C.G., Symbolae physicae. Pars zoologica. Abhandlungen Akademie der Wissenscahften zu Berlin.

EHRENBERG, C.G. 1854. Mikrogeologie das Erden und Felsen schaffende Wirken des unsichtbaren kleinen selbständigen Lebens auf der Erde. Leopold Voss, Leipzig.

ERNISSE, J. and MCCARTNEY, K. 1993. Ebridians. In LIPPS, J.H. (ed.), Fossil prokaryotes and protists. Blackwell Scientific Publications Inc., Boston. pp.131-150.

EVITT, W.R. 1985. Sporopollenin dinoflagellate cysts: their morphology and interpretation. American Association of Stratigraphic Palynologists Foundation, Monograph Series, 1, 333pp. AASP Foundation, Austin, Texas.

EVITT, W.R., DAMASSA, S.P. and ALBERT, N.R. 1998. A tiger by the tail: the exophragm of the Cretaceous-Paleocene dinoflagellate Palaeoperidinium and its implications. Palynology, 22, 1-55.

FENSOME, R.A., TAYLOR, F.J.R., NORRIS, G., SARJEANT, W.A.S., WHARTON, D.I. and WILLIAMS, G.L. 1993. A classification of living and fossil dinoflagellates. Micropaleontology Special Publication, 7, 351pp.

GAHL, H. 1964. Paläontologie und Stratigraphie der tertiären Vorkommen von Sieblos und Obernhausen in der Rhön. Dissertation, University of Geißen, 50pp. 
GAHL, H. 1968. Die unteroligozäne Braunkohlen-lagerstätte von Sieblos/Rhön. Notizbl. hessen

L.-Amt. Bodenforschungen, 96, 259-272.

GAUDANT, J. 1985. Mise au point sure les Vertébrés inférieurs de l'Oligocene de Sieblos (Hesse, Allemagne). Comptes Rendues de l'Academie des Sciences, Paris, ser. 2, 300, 185-188.

HARDING, I. C. 1996. Rediscovery of the type lithology of the siliceous dinoflagellate genus Peridinites Lefèvre 1933 in Eocene sediments of Barbados. Caribbean Journal of Science, 32, 6471.

GRAY, D. ZONNEVELD, K. A. and VERSTEEGH, G. J., 2017. Species-specific sensitivity of dinoflagellate cysts to aerobic degradation: A five-year natural exposure experiment. Review of Palaeobotany and Palynology, 247, 175-187.

GURDEBEKE, P. R. MERTENS, K. N. BOGUS, K. MARRET, F. CHOMÉRAT, N. VRIELINCK, H. and LOUWYE, S., 2018. Taxonomic re-investigation and geochemical characterization of Reid's (1974) species of Spiniferites from holotype and topotype material. Palynology, 42, Supplementary issue, 93-110.

HAECKEL, E., 1894. Systematische Phylogenie. Entwurf eines natürlichen Systems der Organismen auf Grund ihrer Stammesgeschichte. 1. Systematische Phylogenie der Protisten und Pflanzen. Reimer, Berlin, XV + 400pp.

HARDING, I. C. and LEWIS, J. 1994. Siliceous dinoflagellate thecal fossils from the Eocene of Barbados. Palaeontology, 37, 825-840.

HASSENKAMP, E. 1858. Geognotische Beschreibung der Braunkohlenformation in der Rhön. Verhandlungen physikalische-medizinische Gesellschaft Würzburg, 8, 185-211.

HOPKINS, J.A. and MCCARTHY, F.M.G. 2010. Post-depositional palynomorph degradation in quaternary shelf sediments: A laboratory experiment studying the effects of progressive oxidation. Palynology, 26, 167-184. 
HOTTENROTT, M. 1988. Palynostratigraphische Untersuschungen im Oligozän von Sieblos/Rhön. Beiträge fur Naturkunde in Osthessen, 24, 93-98.

IEPURE, S., NAMIOTKO, T., VALDECASAS, A.G. and MAGYARI, E.K. 2012. Exceptionally wellpreserved giant spermatozoa in male and female specimens of an ostracod Cypria ophtalmica (Crustacea: Ostracoda) from Late Glacial lacustrine sediments of Southern Carpathians, Romania Naturwissenschaften, 99, 587-590.

JÄHNICHEN, H. and RÜFFLE, L. 1988. Die altertertiäre Blätterflora aus dem Dysodil von Sieblos an der Wasserkuppe/Rhön. Beiträge fur Naturkunde in Osthessen, 24, 67-92.

JÖRGENSEN, E., 1912. Bericht über die von der schwedischen Hydrographisch-Biologischen Kommission in den schwedischen Gewässern in den Jahren 1909-1910 eingesammelten Planktonproben. Svenska Hydrografisk-Biologiska Kommissionens Skrifter, 4, 1-20.

KADOLSKY, D. 1988. Mollusken aus dem Oligozän von Sieblos an der Wasserkuppe/Rhön. Beiträge fur Naturkunde in Osthessen, 24, 99-129.

KACZMARSKA, I. and EHRMAN, J.M. 1990. Pyritized diatoms in the sediments at the distal end of the Bengal Fan. In COCHRAN, J.R., STOW, D.A.V. et al. (eds.). Proceedings of the Deep Sea Drilling Program, Scientific Results, 116, 243-247.

KAKUWA, Y. 1984. Preservation of siliceous skeletons in siliceous rocks. Scientific Papers of the College of Arts and Sciences, University of Tokyo, 34, 43-61.

KEMP, A.E.S., PIKE, J., PEARCE, R.B. and LANGE, C.B. 2000. The 'fall dump': a new perspective on the role of a shade flora in the annual cycle of diatom production and export flux. Deep-Sea Research II, 47, 2129-2154.

KEMP, A.E.S., DEAN, J.M., PEARCE, R.B. and PIKE, J. 2001. Recognition and analysis of bedding and sediment fabric features. In LAST, W.M and SMOL, J.P. (eds.), Tracking environmental change using lake sediments, 2, 7-22. Kluwer, Dordrecht. 
KODRAN-NSIAH, M., MÄRZ, C., HARDING, I.C., KASTEN, S. and ZONNEVELD, K.A.F. 2009.

Are the Kimmeridge Clay deposits affected by "burn-down" events? Palynological and geochemical studies on a 1 metre long section from the Upper Kimmeridge Clay Formation (Dorset, UK).

Sedimentary Geology, 222, 301-313.

KRASSKE, G. 1934. Die Diatomeenflora der hessischen Kiesel- gurlager. Sitzungsberichte der Heidelberger Akademie der Wissenschaften, Abhandlung 5, 26 p.

LUTZ, H. 1998. Die underoligozäne Insekten-Taphozönose von Sieblos/Rhön - ein Schüssel für die Rekonstrucktion des aquatischen Paläoenvironments. Geologisches Abhandlungen Hessen, $104,101-114$.

MATZKE-KARASZ, R., SMITH, R.J., SYMONOVA, R., MILLER, C.G. and TAFFOREAU, P. 2009. Sexual intercourse involving giant sperm in Cretaceous ostracode. Science, 324, 1535.

MALZ, H. 1988. Ostracoden aus dem Unter-Oligozän von Sieblos an der Wasserkuppe/Rhön. Beiträge fur Naturkunde in Osthessen, 24, 131-136.

MARTIN, R.E., PATTERSON, R.T., GOLDSTEIN, S.T. and KUMAR, A. (eds.) (1999). Special issue: Taphonomy as a tool in paleoenvironmental reconstruction and environmental assessment. Palaeogeography, Palaeoclimatology, Palaeoecology, 149, 434pp.

MARTINI, E. 1965a. Die Fischfauna von Sieblos/Rhön (Oligozän). 1: Smerdiss-Skelette mit Otolithen in situ. Senkenbergiana Lethaea, 46a, 291-305.

MARTINI, E. 1965b. Die Fischfauna von Sieblos/Rhön (Oligozän). 2: Fischreste aus Koprolithen. Senkenbergiana Lethaea, 46a, 307-314.

MARTINI, E. 1987. Nannoplankton aus dem nordhessichen Melanienton und von Sieblos/Rhön (Unter-Oligozän). Geologisches Jahrbuch Hessen, 115, S.161-169.

MARTINI, E. 1988a. Fische aus dem Unter-Oligozän von Sieblos an der Wasserkuppe/Rhön. Beiträge fur Naturkunde in Osthessen, 24, 149-160. 
MARTINI, E. 1988b. Vogelreste aus dem Unter-Oligozän von Sieblos/Rhön. Beiträge fur Naturkunde in Osthessen, 24, 175-177.

MARTINI, E. 1990. The Rhinegraben system, a connection between northern and southern seas in the European Tertiary. Veroffentlichungen Übersee-Museum, A 10, 83-98, 208-211.

MARTINI, E. 1991. Endemische Vertreter der Gattung Trochoaster (kalkiges Nannoplankton) im westdeutschen Unter-Oligozän. Geologisches Jahrbuch, A 128, 167-177.

MARTINI, E. and ROTHE, P. 1993. Sieblos - a lower Oligocene Messel-type deposit. Kaupia, 2, $39-53$.

MARTINI, E. and ROTHE, P. 1998. Sieblos an der Wasserkuppe: Forschungsbohrungen in einem alttertiären See. Geologisches Abhandlungen Hessen, 104, 7-27.

MARTINI, E. and SCHILLER, W. 1998. Kalkiges Nannoplankton von Sieblos/Rhön und dem Neuwieder Becken (Unter-Oligozän). Geologisches Abhandlungen Hessen, 104, 165-172.

MARTINI, E. and SCHRADER, H. 1988. Diatomeen, Chrysophyceen, Nannoplankton, Dinoflagellaten und Schwammnadeln aus dem Unter-Oligozän von Sieblos/Rhön. Beiträge fur Naturkunde in Osthessen, 24, 55-60.

MARTINI, E. and WEILER, H. 1998. Zum Vorkommen von kieselingen Dinoflagellaten in den unteroligozänen Sieblos-Schichten der Rhön. Geologisches Abhandlungen Hessen, 104, 157164.

MAY, F.E. 1976. Dinoflagellates: fossil motile-stage tests from the Upper Cretaceous of the northern New Jersey coastal plain. Science, 193, 1128-1130.

MAY, F.E. 1977. Functional morphology, paleoecology, and systematics of Dinogymnium tests. Palynology, 1, 103-121.

PASCHER, A., 1914. Über Flagellaten und Algen. Deutsche Botanische Gesellschaft, Berichte, 32, 136-160. 
RICHTER, G. and STORCH, G. 1988. Ein Fledermaus-Fund in oligozänen Dysodil von sieblos/Rhön. Beiträge fur Naturkunde in Osthessen, 24, 197-203.

ROTHE, P. 1999. Sieblos, ein 35 Millionen Jahre alter See in der Rhön: Haldenfunde und Forschungsbohrungen. Jahresbericht Verein fur Naturkunde, 6, 133-147.

ROTHE, P. 2006. Mineralogische und geochemische Untersuchungen Sedimenten der Forschungsbohrungen Sieblos 1998 und 1999 (Wasserkuppe/Rhön). Geologisches Jahrbuch Hessen, 133, 83-94.

SCHAUDERNA, H. 1983. Die Diatomeenflora aus den Miozänen Seeablagerungen im Nördlinger Ries. Palaeontographica, B 188, 83-193.

SCHILLER, W. 1998. Kieselige Mikrofossilien aus dem Unter-Oligozän von Sieblos/Rhön. Geologisches Abhandlungen Hessen, 104, 173-199.

SCHLEICH, H.H. 1988. Reptilien- und Amphibien-reste von der oligozänen Fundstelle Sieblos an der Wasserkuppe. Beiträge fur Naturkunde in Osthessen, 24, 161-167.

SCHRANK, E. 1988. Effects of chemical processing on the preservation of peridinioid dinoflagellates: a case from the Late Cretaceous of NE Africa. Review of Palaeobotany and Palynology, 56, 123-140.

SCHWARZ, J. 1988. Charophyten aus dem Unter-Oligozän von Sieblos/Rhön. Beiträge fur Naturkunde in Osthessen, 24, 55-60.

SIVETER D.J, SUTTON, M.D, BRIGGS, D.E.G and SIVETER, D.J. 2003. An ostracode crustacean with soft parts from the lower Silurian. Science, 302, 1749-1751. doi:10.1126/science.1091376

SIVETER, D.J., BRIGGS, D.E.G., SIVETER, D.G. and SUTTON, M.D. 2010. An exceptionally preserved myodocopid ostracod from the Silurian of Herefordshire, UK. Proceedings of the Royal Society $B, \mathbf{2 7 7}, 1539-1544$. 
SPEISSER, P. 1914. Die Braunkohlenformation von Sieblos in der Rhön. Techn. BI. (W.-Beil. Deutsch. Bergwerks-Ztg.), 4, 1-3.

STRENG, M., BANASOVÁ, M., REHÁKOVÁ, D. and WILLEMS, H. 2009. An exceptional flora of calcareous dinoflagellates from the middle Miocene of the Vienna Basin, SW Slovakia, Review of Palaeobotany and Palynology, 135, 225-244. doi:10.1016/j.revpalbo.2008.08.004.

Tangen, K. Brand, L.E., Blackwelder, P.L. and Guillard, R.R.L., 1982. Thoracosphaera heimii (Lohmann) Kamptner is a dinophyte: Observations on its morphology and life cycle. Marine Micropaleontology, 7, 193-212.

THEIN, J., and RAD, U. von 1987. Silica diagenesis in continental rise and slope sediments off eastern North America (Sites 603 and 605, Leg 93; Sites 612 and 613, Leg 95). In POAG, C.W., WATTS, A.B., et al., Initial Reports of the Deep Sea Drilling Project, 95: 501-525.

VAN BEUSEKOM, J.E.E., BENNEKOM, A.J. VAN, TRE'GUER, P. and MORVAN,J. 1997. Aluminium and silicic acid in water and sediments of the Enderby and Crozet Basins. Deep-Sea Research I, 144, 987-1003.

VERSTEEGH, G.J.M. and ZONNEVELD, K.A.F. 2002. Use of selective degradation to separate preservation from productivity. Geology, 30, 615-618.

VERSTEEGH, G. J. M. BLOKKER, P. WOOD, G. COLLINSON, M. E. SINNINGHE DAMSTÉ, J. S. and DE LEEUW, J. W., 2004. An example of oxidative polymerization of unsaturated fatty acids as a preservation pathway for microalgal organic matter. Organic Geochemistry, 35, 1129-1139.

WILLMANN, R. 1988. Der oligozäne Lebensraum von sieblos/Rhön im Spiegel seiner Insekten. Beiträge fur Naturkunde in Osthessen, 24, 143-148.

WOLFE, A.P., EDLUND, M.B., SWEET, A.R. and CREIGHTON, S.D. 2006. A first account of organelle preservation in Eocene nonmarine diatoms: observations and paleobiological implications. Palaios, 21, 298-304. doi10.2110/palo.2005.p05-14e 
ZONNEVELD, K.A.F. and BRUMMER, G.-J.A. 2000. (Palaeo-)ecological significance, transport and preservation of organic walled dinoflagellate cysts in the Somali Basin, NW Arabian Sea. Deep Sea Research Part II, 47, 2229-2256.

ZONNEVELD, K.A.F., VERSTEEGH, G.J.M., and DE LANGE, G.J. 1997. Preservation of organicwalled dinoflagellate cysts in different oxygen regimes: a 10,000 year natural experiment. Marine Micropaleontology, 29, 393-405.

ZONNEVELD, K.A.F., VERSTEEGH, G.J.M., and DE LANGE, G.J. 2001. Palaeoproductivity and post-depositional aerobic organic matter decay reflected by dinoflagellate cyst assemblages of the Eastern Mediterranean S1 sapropel. Marine Geology, 172, 181-195.

ZONNEVELD, K.A.F., BOCKELMANN, F. and HOLZWARTH, U. 2007. Selective aerobic degradation of organic-walled dinoflagellates as tool to quantify past net primary production and bottom water oxygen concentrations. Marine Geology, 237, 109-126.

ZONNEVELD, K.A.F., VERSTEEGH, G.J.M. and KODRANS-NSIAH, M. 2008. Preservation of Late Cenozoic organic-walled dinoflagellate cysts: a review. Marine Micropaleontology, 86, 179_ 197.

ZONNEVELD, K. A. F. GRAY, D. D. KUHN, G. and VERSTEEGH, G. J. M., 2019.

Postdepositional aerobic and anaerobic particulate organic matter degradation succession reflected by dinoflagellate cysts: The Madeira Abyssal Plain revisited. Marine Geology, 408, 87109.

ZONNEVELD, K.A.F., VERSTEEGH, G.J.M., KASTEN, S., EGLINTON, T.I., EMEIS, K.-C., HUGUET, C., KOCH, B.P., DE LANGE, G.J., DE LEEUW, J.W., MIDDELBURG, J.J., MOLLENHAUER, G. PRAHL, F.G., RETHEMEYER, J. and WAKEHAM, S.G. 2010. Selective preservation of organic matter in marine environments; processes and impact on the sedimentary record. Biogeosciences, 7, 483-511. 


\section{FIGURE CAPTIONS}

Fig. 1. Map of the former Sieblos pit workings with the positions of research boreholes shown. Inset map shows the location of Sieblos in northern Germany, and the supposed position of the Oligocene shoreline (based on Martini 1987 and Martini and Rothe 1993).

Fig. 2. Logs of the stratigraphic successions identified in the Sieblos boreholes, indicating the position of Sieblos Shales and the sampled succession in borehole 1994/2 (after Martini \& Rothe 1998 and Rothe 2006).

Fig. 3. Sieblos Taphofacies 1, developed in the bituminous shales. Micrographs from sample $1994 / 2,27.00 \mathrm{~m}$, and scale bar $=20 \mu \mathrm{m}$ unless otherwise stated. SEI = secondary electron microscope image; BSEI = backscattered electron microscope image .

A, SEI of sediment chip fractured parallel to lamination, showing lamina of isolated, disaggregated dinoflagellate thecal plates. Arrow indicates isolated cingular plate.

$\mathrm{B}$, as in A, showing isolated dinoflagellate thecal plates and one associated Cocconeis sp. diatom frustule.

C, BSEl of polished section perpendicular to lamination, showing scale and composition of individual laminae within 'annual' layers. Each biogenic layer is dominated by dinoflagellate thecal plates seen largely in cross-section. Note also the sections through spherical chrysophyte cysts in couplets 3, 8 and 9; the largest silt grains (pale grey) are in couplets 1 and 7 . Scale bar $=100 \mu \mathrm{m}$ $\mathrm{D}$ and $\mathrm{E}, \mathrm{BSEl}$ of polished section perpendicular to lamination, showing variability in thickness and lateral extent of individual laminae within 'annual' layers: layer 3 especially demonstrates lateral thickness variations, the clay lamina being virtually absent to the left- and right-hand extremities of micrograph. The bright (white) sections through thecal plates in couplets 2 and 5 have been pyritised. White square represents the area seen in E. Scale bar $=100 \mu \mathrm{m}$. E. Detail of D, showing the stacking and nesting of isolated dinoflagellate thecal plates in sectional view, in most cases sub-parallel to laminations. Note section through chrysophyte cyst (c); s = silt grain; arrow indicates dinoflagellate thecal plate orientated parallel to section. Scale bar $=10 \mu \mathrm{m}$ 
F, BSEI, perpendicular to lamination, showing detail of lamina consisting of intermixed pennate diatoms (dominating right side of micrograph) and disaggregated dinoflagellate thecal plates. Sample 1994/2, 27.90m.

G, SEl of laminar surface covered in isolated dinoflagellate thecal plates, squares represent areas analysed by EDX. Scale bar $=10 \mathrm{um}$

$\mathrm{H}$, SEl of lamina consisting of isolated dinoflagellate thecal plates overlain (to bottom of micrograph) by clay lamina. Scale bar $=50 \mu \mathrm{m}$

I, SEI of section oblique to lamination showing clay-rich lamina (bottom left) overlain by lamination dominated by matted pennate diatoms with subsidiary chrystophyte cysts. Sample 1994/2, $28.30 \mathrm{~m}$.

J, BSEI perpendicular to lamination, showing (at base) lamina 1 dominated by elongate pennate diatoms and dissociated dinoflagellate thecal plates, isolated clots of chrysophyte cysts (white arrow) and rare sponge spicules (sp). Lamina 2 is comprised of dissociated dinoflagellate thecal plates and diatom resting spores (seen in section) similar to Chaetoceras (Ch), Sample 1994/2, $27.90 \mathrm{~m}$. Scale bar $=100 \mu \mathrm{m}$

Fig. 4. Sieblos Taphofacies 2, developed in the micrites. Micrographs from sample 1994/2, 28.05 $\mathrm{m}$, and scale bars $=20 \mu \mathrm{m}$ unless otherwise stated.

A, SEl of section parallel to lamination showing microcrystalline calcitic groundmass showing two partial external moulds of dinoflagellate thecae $(\mathrm{m})$, two partial internal casts of thecae (arrows) demonstrating calcite crystal faces, and two almost complete internal casts templating the internal morphology of the thecal plates. All the siliceous thecal plates have been lost through dissolution. Sample 1994/2, $29.40 \mathrm{~m}$.

B, SEl of section perpendicular to layering showing lamina dominated by dinoflagellate remains, both disaggregated thecal plates and three-dimensionally preserved dinoflagellates including external moulds $(\mathrm{m})$ and internal casts of theca (three complete specimens to top of lamina). Overlain (top quarter of micrograph) by a less biogenic micritic layer. Rare external moulds of chrysophyte cysts (c) scattered throughout. Sample 1994/2, 28.30 m.

C, as for A and B. Sample 1994/2, $29.40 \mathrm{~m}$. 
D, BSEl showing five numbered 'annual' layers each consisting of a (darker) diatom/dinoflagellate lamina and a (lighter) dinoflagellate-dominated lamina, with scattered articulated and calcite-filled ostracods (o). Scale bar $=1 \mathrm{~mm}$.

$\mathrm{E}$ and J, BSEls showing features as described for Fig. 4, showing three numbered 'annual' layers. $\mathrm{J}$ is a detail of area indicated in $\mathrm{E}$. Both scale bars $=100 \mu \mathrm{m}$.

F, BSEI showing external moulds of three dinoflagellate thecae in diatom-dinoflagellate lamina. Small polygonal voids (black) are external moulds of pennate diatoms.

G, BS showing features as described for Fig. 4, but only two complete 'annual' layers. Scale bar $=100 \mu \mathrm{m}$.

$H$, BSEI detail of dinoflagellate-rich lamina in micrites showing sections through threedimensionally preserved, calcite-filled dinoflagellate thecae in addition to mouldic porosity resulting from dissolution of dissociated thecal plates.

I, BSEI showing detail of single external mould of a dinoflagellate theca in diatom-dinoflagellate lamina in micrites, note proliferation of external moulds of pennate diatoms.

Fig. 5. Secondary electron micrograph images of internal casts of Sieblososphaera martinii n. sp. Specimen numbers relate to the numbered specimens on the sediment chip from sample 1994/2, $29.40 \mathrm{~m}$. Scale bars $=10 \mu \mathrm{m}$, unless otherwise stated.

A, apico-ventral view showing diamond-shaped first apical (1') plate, and penitabular lines of verrucae representing infills of trichocyst pores. Specimen 8, CAMSM X 50335 ah.

B, oblique left-ventral view of specimen, note evidence for pentabular trichocyst pores and plate overlap displayed well on margins of second postcingular (2"') plate. Specimen 7, CAMSM X 50335 ag.

C, antapico-ventral view showing antapical plates and straight right hand margin to sulcus. Specimen 5, CAMSM X 50335 ae.

$D$ and $E$, showing apical tabulation, including the two hexagonal anterior intercalary plates.

Specimens 9 and 6, CAMSM X 50335 ai and X 50335 af, respectively.

F, ventral view, note slightly dislodged apical horn. Specimen 3, CAMSM X 50335 ac.

G, antapico-ventral view showing antapical tabulation. Specimen 10, CAMSM X 50335 aj. 
$H$, ventral view showing left cingular tabulation. Specimen 11, CAMSM X 50335 ak.

I, left apico-ventral view, specimen with narrow growth bands. Specimen 2, CAMSM X 50335 ab.

J, holotype. Ventral view showing complete ventral tabulation pattern, including sulcal plates.

Specimen 14, CAMSM X 50335 ba.

$\mathrm{K}$, apico-dorsal view demonstrating presence of only two anterior intercalary plates (1a, 2a).

Specimen 12, CAMSM X 50335 al.

$\mathrm{L}$, detail of relatively narrow growth bands on hyposome of incompletely preserved specimen.

Specimen 13, CAMSM X 50335 am.

$M$, an unusual specimen preserving strongly reticulate internal morphology of original hyposomal plates. Specimen 15, CAMSM X 50335 an.

$\mathrm{N}$, detail of striate growth bands on plate margins illustrating plate overlap pattern. Specimen 16, CAMSM X 50335 ao.

Fig. 6. Secondary electron micrograph images of Sieblososphaera martinii n. sp. Specimens from sample 1994/2, $29.40 \mathrm{~m}$, and scale bar $=10 \mu \mathrm{m}$, unless otherwise stated.

$A$ and $B$, image of external mould $(A)$ and inverted image $(B)$ showing 'reconstruction' of original theca in oblique left-apical view demonstrating strongly reticulate plate surfaces. Specimen 25 , CAMSM X 50335 au.

C, inverted image of mould preserving left-ventral view of specimen. Specimen 18, CAMSM X 50335 ap.

$D$ and $E$, image of external mould (D) and inverted image $(E)$ of theca in antapical view, showing wide growth bands around margins of third post-cingular (3"') plate. Sample 1994/2, $37.28 \mathrm{~m}$. Specimen 19, CAMSM X 50336 a.

$\mathrm{F}$, inverted image of specimen in ventral view, note completely unobstructed cingulum. Specimen 20, CAMSM X 50335 aq.

$G$ and $H$, image of external mould $(G)$ and inverted image $(H)$ in antapico-ventral view, showing prominent line of four trichocyst pores along antapical margin of posterior sulcal plate. Specimen 21, CAMSM X 5033 ar. 
I and L, inverted images of external mould in right-ventral view. I. Note how theca was preserved as the strongly reticulate plates were beginning to separate from each other. L. Detail of I, collared trichocyst pores indicated by black arrows and dissolution pitting indicated in circled area. Scale bar $=5 \mu \mathrm{m}$. Specimen 22, CAMSM X 50335 as.

$\mathrm{J}$, inverted image of external mould in antapico-ventral view showing prominent longitudinal flagellar pore (arrowed), high septa surrounding posterior sulcal plate which bears a row of trichocyst pores along its antapical margin. Sample 1994/2, 37.28 m. Specimen 23, CAMSM X 50336 b.

$\mathrm{K}$, inverted image of external mould in antapico-ventral view; theca lacks growth bands and demonstrates early stages of thecal disintegration along opening plate sutures. Specimen 24 , CAMSM $\times 50335$ at.

Fig. 7. Exploded plate diagram for Sieblosophaera martinii n. sp., showing tabulation pattern.

Fig. 8. Plate overlap ('tegulation') pattern for Sieblosophaera martinii n. sp., apical tabulation to left, antapical to right. 